\title{
Bromosceptrin, an Alkaloid from the Marine Sponge Agelas conifera
}

Michael A ssmann and M atthias K öck*

A Ifred-Wegener-Institut für Polar- und Meeresforschung, A m Handelshafen 12, D-27570 B remerhaven, Germany. Fax: 0049-471-4831-1425. E-mail: mkoeck@awi-bremerhaven.de

* A uthor for correspondence and reprint requests

Z. N aturforsch. 57 c, 157-160 (2002); received N ovember 2, 2001

Sponges, Agelas, B romopyrrole A Ikaloids

Six dimeric bromopyrrole alkaloids (1-6) were isolated from a Florida Keys specimen of Agelas conifera. O ne of the constituents was identified as a new bromopyrrole metabolite, bromosceptrin (1). The structure of $\mathbf{1}$ was established from M S spectrometry and ID and 2D NMR spectrocopy.

\section{Introduction}

Bromopyrrole alkaloids are well known in marine sponges of the genus Agelas (B raekman et al., 1992). In our search for bioactive substances from marine organisms, a series of brominated dimeric pyrrole alkaloids have been isolated from a specimen of the sponge Agelas conifera collected off the coast of the Florida K eys, Florida, USA. Examination of the dichloromethane/methanol extract of this sponge resulted in isolation of the known alkaloids sceptrin (2), dibromosceptrin(5), ageliferin (3), bromoageliferin (4), and dibromoageliferin (6) which have been previously isolated from Agelas sponges (Walker et al., 1981; Kobayashi et al., 1990; K eifer et al., 1991) as well as of the new bromopyrrole alkaloid, bromosceptrin (1). In this communication we describe the isolation and structure elucidation of $\mathbf{1}$. D ue to the isolation of bromosceptrin (1) the family of the sceptrins is now completed.

\section{Materials and Methods}

The marine sponge Agelas conifera (Schmidt, 1870) (order A gelasida, family A gelasidae) employed in this study was collected in May 1998 at Elbow R eef by SCUBA diving ( $19 \mathrm{~m}$ depth) off the coast of the Florida Keys, Florida, USA. The growth form of the specimen is repent-ramose with volcanoe-shaped oscules, colour in life is brownish, consistency is tough, spongy, firm and almost incompressible. A voucher fragment of the sponge has been deposited under registration no. ZMA POR. 16866 in the Zoölogisch Museum, A msterdam, The $\mathrm{N}$ etherlands.

Samples of Agelas conifera were immediately frozen after collection and kept at $-20^{\circ} \mathrm{C}$ until<smiles>[Y]c1cc(C(=O)NC[C@@H]2[C@H](c3cnc(N)[nH]3)[C@@H](c3cnc(N)[nH]3)[C@@H]2CNC(=O)c2cc([Y])c([Y])[nH]2)[nH]c1[Y]</smiles>

Sceptrin-Skeleton

Sceptrin (2): $X^{1}=B r, X^{2}=H, X^{3}=B r, X^{4}=H$ Bromosceptrin (1): $X^{1}-X^{3}=B r, X^{4}=H$ Dibromosceptrin (5): $X^{1}-X^{4}=B r$<smiles>[Y]c1cc(C(=O)NC[C@H]2Cc3[nH]c(N)nc3[C@@H](c3cnc(N)[nH]3)[C@H]2CNC(=O)c2cc([Y4])c([Z4])[nH]2)[nH]c1[X]</smiles>

Ageliferin-Skeleton

Ageliferin (3): $\mathrm{X}^{1}=\mathrm{Br}, \mathrm{X}^{2}=\mathrm{H}, \mathrm{X}^{3}=\mathrm{Br}, \mathrm{X}^{4}=\mathrm{H}$ Bromoageliferin (4): $X^{1}-X^{3}=B r, X^{4}=H$ Dibromoageliferin (6): $X^{1}-X^{4}=B r$ 
extraction. For bulk extraction followed by isolation of brominated secondary metabolites, freezedried sponge tissue $(269 \mathrm{~g} \approx 1360 \mathrm{ml}$ ) was extracted 3 times in $\mathrm{MeOH}$, twice in a 1:1-mixture of dichloromethane/ $\mathrm{M} \mathrm{eOH}$, and once in dichloromethane at room temperature each. The organic extracts were combined and evaporated to dryness. The obtained crude extract was partitioned between $n$-hexane $(3 \times 500 \mathrm{ml})$ and $\mathrm{MeOH}$ $(150 \mathrm{ml})$. The remaining $\mathrm{MeOH}$ phase was concentrated and the residue ( $10.7 \mathrm{~g}$ ) was purified by gel chromatography on Sephadex LH-20 (Pharmacia) using $\mathrm{MeOH}$ as mobile phase. A part of the fraction containing sceptrins and ageliferins ( $2.03 \mathrm{~g}$, see Fig. 1) was finally purified by preparative R $\mathrm{P}_{18} \mathrm{HPLC}$ (conditions: $5 \mathrm{~min} \mathrm{~A} \mathrm{,} 45 \mathrm{~min} 45 \%$ B; $\mathrm{A}: 10 \% \mathrm{MeCN} / \mathrm{H}_{2} \mathrm{O}+0.1 \% \mathrm{TFA} ; \mathrm{B}: \mathrm{MeCN}+$ $0.1 \%$ TFA ). The following compound proportions approximating those found in the sponge tissue by H PLC quantification can be given: bromosceptrin (1) $(0.05 \mathrm{mg} / \mathrm{ml}$ corresponds to $0.03 \%$ of dry weight), sceptrin (2) $(1.02 \mathrm{mg} / \mathrm{ml} \approx 0.52 \%)$, dibromosceptrin $(5)(0.13 \mathrm{mg} / \mathrm{ml} \approx 0.07 \%)$, ageliferin (3) $(0.07 \mathrm{mg} / \mathrm{ml} \approx 0.04 \%)$, bromoageliferin (4)

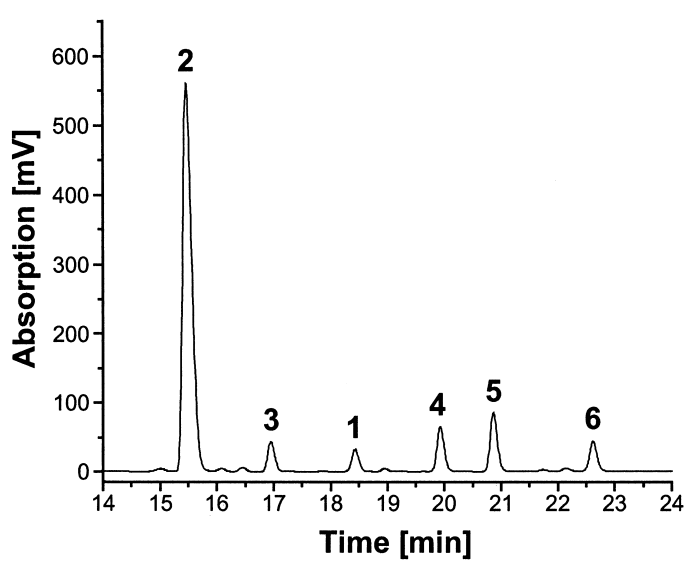

Fig. 1. HPLC profile of a fraction from the $n$-BuOH phase of Agelas conifera which has been purified by Sephadex L H -20 chromatography. This fraction contains only dimeric pyrrole alkaloids with the sceptrin and ageliferin skeleton. The retention times are: sceptrin (2) $t_{R}=15.46 \mathrm{~min}$, ageliferin (3) $t_{R}=16.95 \mathrm{~min}$, bromosceptrin (1) $t_{R}=18.43 \mathrm{~min}$, bromoageliferin (4) $t_{R}=$ $19.93 \mathrm{~min}$, dibromosceptrin (5) $t_{R}=20.87 \mathrm{~min}$, and dibromoageliferin (6) $t_{R}=22.62 \mathrm{~min}$. HPLC conditions: column K romasil R P $\mathrm{P}_{18}, 4.6 \times 250 \mathrm{~mm}, 5$ um; gradient 20 to $60 \% \mathrm{MeCN} / \mathrm{H}_{2} \mathrm{O}+0.1 \% \mathrm{TFA}$ in $40 \mathrm{~min}$; flow rate $1 \mathrm{ml} / \mathrm{min}$.
$(0.12 \mathrm{mg} / \mathrm{ml} \approx 0.06 \%)$, and dibromoageliferin (6) $(0.09 \mathrm{mg} / \mathrm{ml} \approx 0.05 \%)$.

${ }^{1} \mathrm{H} \mathrm{NMR}$ and ${ }^{13} \mathrm{C}$ NMR spectra were recorded on a Bruker DRX 600 NMR spectrometer. A II NMR experiments were measured at $300 \mathrm{~K}$. The 2D experiments $\left({ }^{1} \mathrm{H},{ }^{1} \mathrm{H}-\mathrm{COSY},{ }^{1} \mathrm{H},{ }^{13} \mathrm{C}-\mathrm{HSQC}\right.$, ${ }^{1} \mathrm{H},{ }^{13} \mathrm{C}-\mathrm{HMBC},{ }^{1} \mathrm{H},{ }^{15} \mathrm{~N}-\mathrm{HSQC}$ and ${ }^{1} \mathrm{H},{ }^{15} \mathrm{~N}-$ $\mathrm{HMBC}$ ) were carried out using standard parameters. M ass spectral analysis (HRFA B S) was performed on a JEOL JMS-700 sector-field mass spectrometer with 3-nitrobenzyl alcohol (NBA) as matrix or using a Fison VG Platform II for ESIM S. HPLC analysis and quantification was carried out as previously reported (A ssmann et al., 1999; A ssmann et al., 2000). I R (K B r) spectra were recorded on a Perkin Elmer 1600 Series FT-IR spectrometer. U V N IS spectra were obtained using a Perkin E Imer U V N IS spectrometer L ambda 16.

\section{Results and Discussion}

The compounds $\mathbf{1 - 6}$ could be isolated from a Florida Keys specimen of the marine sponge Agelas conifera. The brominated alkaloids sceptrin (2), dibromosceptrin (5), ageliferin (3), bromoageliferin (4), and dibromoageliferin (6) were identified by comparison of mass spectrometry and N M R data with those previously reported (Walker et al., $1981 \rightarrow$ 2; Kobayashi et al., $1990 \rightarrow \mathbf{3}, \mathbf{4}, 6$; K eifer et al., $1991 \rightarrow \mathbf{2 - 6}$ ). The E SI mass spectrum (negative ion mode) of $\mathbf{1}$ showed prominent pseudomolecular ion peaks at $m / z$ 697, 699, 701, 703 in the ratio $1: 2: 2: 1$, suggesting the presence of three bromine atoms.<smiles>Nc1ncc([C@H]2[C@H](CNC(=O)c3cc(Br)c(Br)[nH]3)[C@@H](CNC(=O)c3cc(Br)c[nH]3)[C@H]2c2cnc(N)[nH]2)[nH]1</smiles>

From this data it cannot be distinguished between the two different skeleton of the dimeric bromopyrrole alkaloids (ageliferin or sceptrin). $\mathrm{D}$ ue to the cyclisation of oroidin type compounds to the dimeric forms new aliphatic protons are generated which can be used as fingerprint region. 
The ageliferin skeleton has three methine and one methylene group in the region between 2.0 and $3.0 \mathrm{ppm}$ whereas the sceptrin skeleton has four methine signals. A nother criterion is the olefinic region since the sceptrin skeleton shows one signal

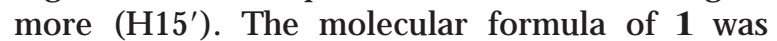
established as $\mathrm{C}_{22} \mathrm{H}_{24}{ }^{79} \mathrm{Br}_{3} \mathrm{~N}_{10} \mathrm{O}_{2}$ by HRFA BMS $\left(\mathrm{m} / \mathrm{z}\right.$ 696.9634, $\left.[\mathrm{M}+\mathrm{H}]^{+}, \Delta+4.1 \mathrm{mmu}\right)$, which is in accordance with the ${ }^{1} \mathrm{H}$ and ${ }^{13} \mathrm{C} N \mathrm{~N} R$ data of the new compound bromosceptrin (1) (see Tablel). The absolute configuration of $\mathbf{1}$ was obtained by comparison of the CD spectral data $(c=43 \mu \mathrm{mol} / /$, $\left.\mathrm{MeOH},[\theta]_{232}-1320\right)$ with the values published in the literature (Walker et al., 1981; Kobayashi et al., 1990; K eifer et al., 1991; Shen et al., 1998). Due to the isolation of bromosceptrin (1), which contains 3 bromines, the family of the sceptrins is completed. The members differ in the degree of bromination. Debromosceptrin (none bromine, Shen et al., 1998), monobromosceptrin (one bromine, Keifer et al., 1991), sceptrin (2, two bromines, Walker et al., 1981) and dibromosceptrin (5, four bromines, Keifer et al. 1991) were already described in the literature.

B romopyrrole alkaloids are known to be feeding deterrent against predatory reef fishes ( $C$ hanas et al., 1996; Wilson et al., 1999; Lindel et al., 2000; A ssmann et al., 2000; A ssmann et al., 2001). The dimeric compounds show a higher activity in comparison to the monomeric counterparts. Interestingly, the activity does not increase by the degree of bromination as known from the monomeric compounds (A ssmann et al., 2000). O nly Sceptrin (2) appears in such concentration in the sponge tissue, which are above the required concentration of a single compound for feeding deterrency.

\section{Acknowledgements}

Financial support from the $D$ eutsche Forschungsgemeinschaft (Ko $1314 / 3-1$ to $3-4$ ) is gratefully acknowledged. Furthermore, we are grateful to Professor Joseph R. Pawlik (D epartment of Biological Sciences and Center for M arine Science, U niversity of N orth Carolina Wilmington, U SA ) for giving M.A. the opportunity to participate in the scientific sojourns to the Florida K eys in M ay 1998, during which the sponge Agelas conifera was collected. We thank the staff of the $\mathrm{N}$ ational $\mathrm{U} \mathrm{n}$ dersea Research Center (NURC) at Key Largo, Florida, for their cooperation. We are grateful to D r. R ob W. M . van Soest (Instituut voor B iodiversiteit en Ecosysteemdynamica, Zoölogisch Museum, U niversiteit van A msterdam, The Netherlands) for his expert help with sponge identification. We thank Ellen Lichte for performing H PLC analyses.

Table I. ${ }^{1} \mathrm{H},{ }^{13} \mathrm{C}$ and ${ }^{15} \mathrm{~N}$ N M R chemical shifts $(\delta)$ of $\mathbf{1}$ in D M SO $-d_{6} \cdot{ }^{a}$

\begin{tabular}{|c|c|c|c|}
\hline Position & & $\delta\left({ }^{13} \mathrm{C}\right) / \delta\left({ }^{15} \mathrm{~N}\right){ }^{\mathrm{b}}$ & $\delta\left({ }^{1} \mathrm{H}\right)^{\mathrm{c}}$ \\
\hline $\begin{array}{l}1\left(1^{\prime}\right) \\
2\left(2^{\prime}\right) \\
3\left(3^{\prime}\right) \\
4\left(4^{\prime}\right) \\
5\left(5^{\prime}\right) \\
6\left(6^{\prime}\right) \\
7\left(7^{\prime}\right) \\
8\left(8^{\prime}\right) \\
9\left(9^{\prime}\right) \\
10\left(10^{\prime}\right) \\
11\left(11^{\prime}\right) \\
12\left(12^{\prime}\right) \\
13\left(13^{\prime}\right) \\
14\left(14^{\prime}\right) \\
15\left(15^{\prime}\right) \\
16\left(16^{\prime}\right)\end{array}$ & $\begin{array}{l}\mathrm{NH} \\
\mathrm{C} \\
\mathrm{CH} \\
\mathrm{C} \\
\mathrm{C} / \mathrm{CH} \\
\mathrm{C} \\
\mathrm{NH} \\
\mathrm{CH}_{2} \\
\mathrm{CH} \\
\mathrm{CH} \\
\mathrm{C} \\
\mathrm{NH} \\
\mathrm{C} \\
\mathrm{NH} \\
\mathrm{CH} \\
\mathrm{NH}_{2}\end{array}$ & $\begin{array}{cl}166 & (161) \\
127.7 & (126.4) \\
112.5 & (111.4) \\
97.7(94.8) \\
104.5(121.2) \\
159.0(159.7) \\
105 \quad(105) \\
40.7 \quad(40.7) \\
41.8 \quad(41.8) \\
37.1(37.1) \\
126.8(126.8) \\
137 \quad(137) \\
146.8(146.8) \\
134 \quad(134) \\
108.9(108.9) \\
58 \quad(58)\end{array}$ & $\begin{array}{cc}12.65 & (11.78) \\
- & \\
6.88 & (6.80) \\
- & \\
& (6.98) \\
- & \\
8.20 & (8.16) \\
3.39 & (3.39) \\
2.27 & (2.27) \\
2.94 & (2.94) \\
- & \\
12.20 & (12.20) \\
- & \\
11.73 & (11.73) \\
6.60 & (6.60) \\
7.37 & (7.37)\end{array}$ \\
\hline
\end{tabular}

a The structure of bromosceptrin (1) was already published (A ssmann et al., 2000), but without any analytical data. ${ }^{b}{ }^{13} \mathrm{C}$ chemical shifts are given in [ppm] and are referenced to the D M SO $-d_{6}$ signal $(39.5 \mathrm{ppm}) .{ }^{15} \mathrm{~N}$ chemical shifts are given in [ppm] and are calibrated according to the B ruker frequency, which is set to $0 \mathrm{ppm}$ for $\mathrm{NH}_{3}$, the accuracy is about 1 to $2 \mathrm{ppm}$.

${ }^{1}{ }^{1} \mathrm{H}$ chemical shifts are given in [ppm] and are referenced to the D M SO- $d_{6}$ signal $(2.50 \mathrm{ppm})$. 
A ssmann $M$, Lichte $E$, Pawlik J $R$ and Köck $M$. (2000), Chemical defenses of the Caribbean sponges Agelas wiedenmayeri and Agelas conifera. M ar. E col. Prog. Ser. 207, 255-262.

A ssmann M., Lichte E., van Soest R. W. M. and Köck M. (1999), N ew bromopyrrole alkaloid from the marine sponge Agelas wiedenmayeri. O rg. L ett. 1, 455-457.

A ssmann M., van Soest R. W. M. and Köck M. (2001), $\mathrm{N}$ ew antifeedant bromopyrrole alkaloid from the $\mathrm{Car}$ ibbean sponge Stylissa caribica. J. Nat. Prod. 64, $1345-1347$.

Braekman J. C, Daloze D., Stoller C. and van Soest R. W. M. (1992), Chemotaxonomy of Agelas (Porifera: D emospongiae). B iochem. Syst. E col. 20, 417-431.

Chanas B., Pawlik J. R., Lindel T. and Fenical W. (1996), Chemical defense of the Caribbean sponge Agelas clathrodes (Schmidt). J. Exp. M ar. Biol. E col. 208, 185-196.

Keifer P.A., Schwartz R.E., Koker M.E.S., Hughes R. G. J r., Rittschof D. and R inehart K. L. (1991), Bioactive bromopyrrole metabolites from the Caribbean sponge Agelas conifera. J. O rg. Chem. 56, 2965-2975, errata 5736, 6728.
Kobayashi J., Tsuda M., M urayama T., Nakamura H. O hizumi Y., I shibashi M., I wamura M., O hta T. and Nozoe S. (1990), A geliferins, potent actomyosin ATPase activator from the Okinawan marine sponge Agelas sp. Tetrahedron 46, 5579-5586.

L indel T., H offmann $\mathrm{H}$., $\mathrm{H}$ ochgürtel $\mathrm{M}$. and Pawlik J. R. (2000), Structure-activity relationship of inhibition of fish feeding by sponge-derived and synthetic pyrroleimidazole alkaloids. J. Chem. E col. 26, 1477-1496.

Shen X., Perry T. L., D unbar C. D., K elly-B orges M . and H amann M. T. (1998), D ebromosceptrin, an alkaloid from the Caribbean sponge Agelas conifera. J. Nat. Prod. 61, 1302-1303.

Walker R. P., Faulkner D. J., van Engen D. and Clardy J. (1981), Sceptrin, an antimicrobial agent from the sponge Agelas sceptrum. J. A m. Chem. Soc. 103, 6772-6773.

Wilson D. M., Puyana M., Fenical W. and Pawlik J.R. (1999), Chemical defense of the Caribbean reef sponge Axinella corrugata against predatory fishes. J. Chem. E col. 25, 2811-2823. 